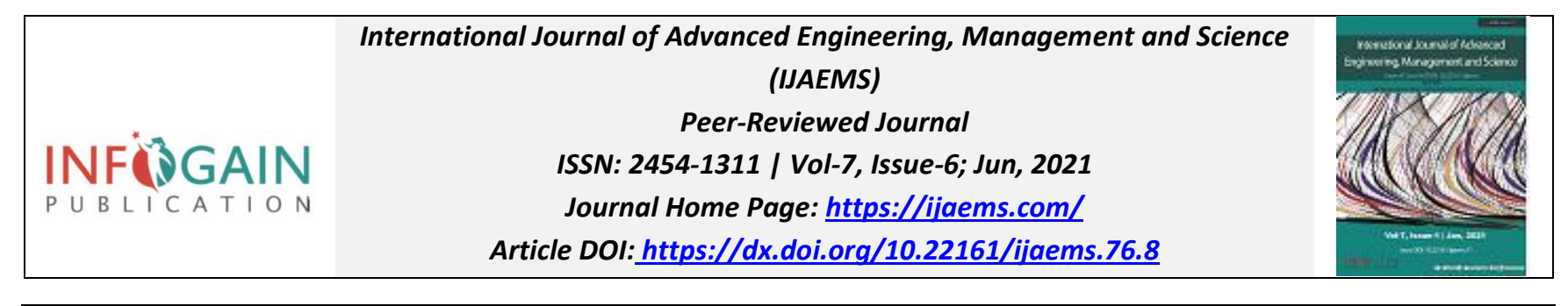

\title{
Comprehensive review on empirical models to estimate global solar radiation on horizontal surfaces
}

\author{
R K Aggarwal \\ Department of Environmental Science, Dr Y S Parmar University of Horticulture \& Forestry, Nauni - Solan (HP), India \\ Email: rajeev1792@ rediffmail.com
}

Received: 18 Apr 2021; Received in revised form: 20 May 2021; Accepted: 02 Jun 2021; Available online: 16 Jun 2021

\begin{abstract}
In the present scenario of global warming and climate change, use of solar energy is becoming imminent. Researchers are working on developing models to predict global solar radiation based on meteorological and geographical parameters. A number of models have been developed in the past which have been summarized in the present study. The techniques to develop models have also been presented. In the era of global warming, the role of air pollutants in estimating GSR is more important than developing very complex models. Models related to this aspect have also been discussed.
\end{abstract}

Keywords - Global solar radiation, models, meteorological parameters and air pollution index.

\section{INTRODUCTION}

The emission of greenhouse gasses is considered to be responsible for climate change, which is a great concern globally. According to a report released by IPCC [1], if the current rate of emissions continues, the temperature of the earth will increase by $1.5^{\circ} \mathrm{C}$ between 2030 and 2052. The rise in temperature is due to emission of GHGs in the atmosphere. The use of fossil fuels is responsible for emission of greenhouse gasses in the environment. The fossil fuels are being used to meet out daily energy needs of the population. In order to meet out energy needs of humankind, the shift from fossil fuels to renewable energy is needed to protect the environment. Solar energy is widely known as sustainable form of energy capable to mitigate the environmental problems in the future [2]. For the designing and performance evaluation of solar energybased system, solar radiation data is required. In the developing countries, the solar radiation measurement equipments are merely available due to their high cost. It necessitates to estimate global solar radiation (GSR) data from meteorological parameters (evaporation, effects of cloudiness, relative humidity, precipitation, temperature, sunshine duration, extraterrestrial solar radiation, and reflection of the environment); geographical parameters (latitude, longitude and altitude of the location); geometrical factors (orientation and inclination angles); astronomical parameters (solar constant, earth-sun distance, solar declination and hour angle); physical parameters (water vapour content, scattering of air molecules, dust and other atmospheric constituents gasses $[3,4]$. The first model proposed for estimating global solar radiation was developed by Angstrom [5] and modified by Prescott [6]. Thereafter, till now 165 sunshine-based models, 62 temperature-based models, 16 RH based, 10 Cloud cover based, one Precipitation based, 103 Hybrid models have been developed by various authors worldwide [7]. Although, all the models are supposed to be best fit for their locations but, still work is going on to develop more accurate empirical model using various meteorological and geographical variables and statistical methods/techniques for particular sites. The aim of this study is to present models that have been developed for predicting GSR at various locations worldwide, which will be useful for many researchers globally.

\section{MODELS DEVELOPED}

The correlation for estimating the global solar radiation on a horizontal surface $\mathrm{H}$ using the sunshine hour data was proposed by Angstrom [5] and Prescott [6] modified the Angstrom correlation as

$$
\frac{\mathrm{H}_{\mathrm{g}}}{\mathrm{H}_{0}}=a+b\left(\frac{n}{N}\right)
$$

This article can be downloaded from here: www.ijaems.com 
where, constants $a$ and $b$ are regression coefficients. $N$ is day length (hours), $n$ is measured sunshine hours, $\mathrm{H}_{\mathrm{g}}$ is estimated GSR and $\mathrm{H}_{0}$ is extraterrestrial GSR calculated as

$$
\begin{aligned}
H o=\frac{24}{\pi} I_{s c}(1+ & \left.0.033 \operatorname{Cos} \frac{360 n}{365}\right)(\operatorname{Cos} \varphi \operatorname{Cos} \delta \operatorname{Cos} \omega \\
& \left.+\frac{\pi}{180} \omega \operatorname{Sin} \varphi \operatorname{Sin} \delta\right)
\end{aligned}
$$

where $\varphi$ is the latitude of the location and $\delta$ is the solar declination angle and $\omega$ is sunset hour angle.

The solar declination angle is given by

$$
\delta=23.45 \operatorname{Sin}\left(\frac{360(284+n)}{365}\right)
$$

where $n$ is the day of the year i.e. January first $n=1$ to 365 days.

The day length is given by

$$
N=\frac{2}{15} \operatorname{Cos}^{-1}(-\operatorname{Tan} \varphi \operatorname{Tan} \delta)
$$

The sunset hour angle is given by

$$
\omega=\operatorname{Cos}^{-1}(-\operatorname{Tan} \varphi \operatorname{Tan} \delta)
$$

Some of empirical models based on the Angstrom-Prescott model and other modified (exponential form, logarithm form, second order to $7^{\text {th }}$, order, power form and also reverse form) models used for estimating global solar radiation have been presented in Table 1 . The first-order polynomial function of the relative sunshine duration has been developed by number of author, but few of them are presented in table 1 . In other categories also, few models with latest findings have been presented in the study. Page [8] in 1961 gave the simplest correlation which is still found to be best fit for many locations. After that various author have modified and included many parameters to have accurate correlation for their locations. Glover [9] in 1958 introduced latitude of the location for estimating GSR valid for latitude less than $60^{\circ}$, Torgul [10] in 1999 included declination angle of the location to estimate GSR. Hay [11] was of opinion that the coefficient $a$ and $b$ in Angstrom type equations have the optical properties effects of the cloud cover, ground reflectivity, and average air mass. He incorporated the ground albedo $\rho$, cloudless sky albedo $\rho_{a}$ and cloud albedo $\rho_{c}$. The numerical This article can be downloaded from here: www.ijaems.com constants were obtained by assuming $\rho_{a}=0.25$ and $\rho_{c}=$ $0.6, \mathrm{~N}$ is the modified day length. Rensheng [12] developed the model by considering latitude, longitude and elevation (amsl) of the location in China. In quadratic type of models, $2^{\text {nd }}$ order polynomial equations were developed by Ogelman [13]. In cubic type of models, $3^{\text {rd }}$ order polynomial equations were developed by Bahel [14]. $4^{\text {th }}$ order polynomial equation was developed by Shahrukh [15] in 2019 using sunshine hours data. $5^{\text {th }}$ and $7^{\text {th }}$ order polynomial relationship between the monthly average values of $\left(\mathrm{H}_{\mathrm{g}} / \mathrm{H}_{\mathrm{o}}\right)$ and $(\mathrm{n} / \mathrm{N})$ were developed by Bakirci [16]. Argungu [17] developed the model incorporated temperature $(\theta)$ of the location and logarithm of relative humidity. Almorox [18] studied the various models and found that third order models have performed better than the other models, but the linear model was preferred due to its greater simplicity and wider application. Shahrukh [15] proposed new model in terms of exponential of sunshine hour. Torgul [19] in 2002 and recently Shahrukh [15] developed the models of power type to estimate GSR. Alhassan [20] developed a reverse model and showed that the linear and reverse models were more accurate, and logarithmic model showed the least accurate model with low values of R. Newland [21] in 1988 developed algorithm model to estimate GSR which was recently modified by Shahrukh [15] in 2019. Shahrukh [15] in 2019 developed simple empirical model although there were more than 160 models already available globally. Quartic model was fund to be best fit among cubic, quadratic, exponential, power in their study for Indian locations.

The statistical tests revealed that no single model can be used with higher degree of accuracy for the estimation of GSR at different geographical and climatic locations in Pakistan [22]. Ninomiya [23] considered the effect of rainy days while estimating the GSR. Chandel [24] model based on sunshine hour was found to be best fit for Indian sites. Marwal [25] found that cubic correlation was the best while logarithmic correlation has proved to be worst for Jaipur, Rajasthan (India). They proposed power correlation which showed the values of statistical parameters close to cubic and has a simple form. Kadir [26] found that the monthly linear models and $7^{\text {th }}$ order correlation provided the best estimate of GSR with low errors. They proposed linear equations of each month and seventh order equation for estimating GSR for Erzurum, Turkey. Meenal [27] showed that sunshine duration-based model produced best result with a coefficient of determination $\left(\mathrm{R}^{2}=0.9784\right)$. Soufi [28] found that the quadratic model did not produce better values of GSR. Moreover, the results showed that the correlation of global solar radiation with sunshine hours, air temperature, relative humidity had very accurate estimates for their sites $\left(\mathrm{R}^{2}=0.997\right)$. Muhammad [29]

68 
reviewed the number of models and found that GSR depends upon atmospheric layer, distance between sun and earth, incident angle of solar radiation, day length and rotation of earth, etc. Aggarwal [30] found a new correction factor to estimate GSR. Kumar [31] has developed new correlation using ANN techniques. Suthar [32] proposed an exponential quadratic model incorporating sunshine hour and air pollution index to estimate GSR for Indian cities after considering other regression models e.g., linear, quadratic, exponential linear and exponential quadratic. They were the opinion that air pollution was major significant factor instead of location for predicting GSR.

Table 1. Models developed for the estimation of global solar radiation

\begin{tabular}{|c|c|c|c|c|}
\hline $\begin{array}{l}\text { S. } \\
\text { No. }\end{array}$ & \multirow{2}{*}{$\begin{array}{l}\text { Type of } \\
\text { Model } \\
\text { Linear }\end{array}$} & \multicolumn{2}{|c|}{ Equation } & \multirow{2}{*}{$\begin{array}{l}\text { Reference } \\
\text { Glover Mc-Culloch } \\
\text { (1958) }\end{array}$} \\
\hline & & i) & $\frac{\mathrm{H}_{\mathrm{g}}}{\mathrm{H}_{0}}=(0.29+\operatorname{Cos} \varphi)+0.52\left(\frac{n}{N}\right)$ & \\
\hline & & iii) & $\frac{\mathrm{H}_{\mathrm{g}}}{\mathrm{H}_{0}}=\frac{0.1572+0.5566 \frac{n}{N}}{1-\rho\left\{\rho_{a}\left(\frac{n}{N}\right)+\rho_{c}\left(1-\frac{n}{N}\right)\right.}$ & Hay (1997) \\
\hline & & ii) & $\begin{array}{l}H_{g}=-1.3876+0.518 H_{0}+2.3064\left(\frac{n}{N}\right) \\
H_{g}=2.765+4.9597 \operatorname{Sin} \delta+2.2984\left(\frac{n}{N}\right)\end{array}$ & Togrul (1999) \\
\hline & & iv) & $\begin{array}{c}\frac{\mathrm{H}_{\mathrm{g}}}{\mathrm{H}_{0}}=\left(0.275+4.27 x 10^{-5} \lambda-0.141 \operatorname{Cos} \varphi+2.6310^{-2} Z\right) \\
+0.542\left(\frac{n}{N}\right)\end{array}$ & Rensheng (2004) \\
\hline & & v) & $\frac{\mathrm{H}_{\mathrm{g}}}{\mathrm{H}_{0}}=0.2030+0.4836\left(\frac{n}{N}\right)$ & Shahrukh 2019 \\
\hline \multirow[t]{2}{*}{2} & Quadratic & i) & $\frac{\mathrm{H}_{\mathrm{g}}}{\mathrm{H}_{0}}=0.195+0.676\left(\frac{n}{N}\right)-0.142\left(\frac{n}{N}\right)^{2}$ & Ogelman (1984) \\
\hline & & ii) & $\frac{\mathrm{H}_{\mathrm{g}}}{\mathrm{H}_{0}}=0.4114+0.2163\left(\frac{n}{N}\right)+0.5469\left(\frac{n}{N}\right)^{2}$ & Shahrukh (2019) \\
\hline \multirow[t]{2}{*}{3} & Cubic & i) & $\frac{\mathrm{H}_{\mathrm{g}}}{\mathrm{H}_{0}}=0.16+0.87\left(\frac{n}{N}\right)-0.61\left(\frac{n}{N}\right)^{2}+0.34\left(\frac{n}{N}\right)^{3}$ & Bahel (1986) \\
\hline & & ii) & $\frac{\mathrm{H}_{\mathrm{g}}}{\mathrm{H}_{0}}=0.6949-1.8976\left(\frac{n}{N}\right)+3.5126\left(\frac{n}{N}\right)^{2}-1.6201\left(\frac{n}{N}\right)^{3}$ & Shahrukh (2019) \\
\hline 4 & $4^{\text {th }}$ Order & i) & $\begin{aligned} \frac{\mathrm{H}_{\mathrm{g}}}{\mathrm{H}_{0}}=-0.0877+ & 4.3380\left(\frac{n}{N}\right)-13.4870\left(\frac{n}{N}\right)^{2} \\
& +17.7210\left(\frac{n}{N}\right)^{3}-7.8622\left(\frac{n}{N}\right)^{4}\end{aligned}$ & Shahrukh (2019) \\
\hline 4 & Fifth order & i) & $\begin{aligned} \frac{\mathrm{H}_{\mathrm{g}}}{\mathrm{H}_{0}}=-11.225+ & 128.010\left(\frac{n}{N}\right)-516.900\left(\frac{n}{N}\right)^{2} \\
& +994.730\left(\frac{n}{N}\right)^{3}-920.350\left(\frac{n}{N}\right)^{4} \\
& +329.93\left(\frac{n}{N}\right)^{5}\end{aligned}$ & Bakirci (2008) \\
\hline 5 & $\begin{array}{l}\text { Seventh } \\
\text { order }\end{array}$ & i) & $\frac{\mathrm{H}_{\mathrm{g}}}{\mathrm{H}_{0}}==78.8586-1242.8537\left(\frac{n}{N}\right)+8141.6012\left(\frac{n}{N}\right)^{2}-$ & Bakirci (2008) \\
\hline
\end{tabular}




\begin{tabular}{|c|c|c|c|c|}
\hline & & & $\begin{array}{l}28578.4590\left(\frac{n}{N}\right)^{3}+58196.6890\left(\frac{n}{N}\right)^{4}-68955.3040\left(\frac{n}{N}\right)^{5}+ \\
44150.5770\left(\frac{n}{N}\right)^{6}-11817.7990\left(\frac{n}{N}\right)^{7}\end{array}$ & \\
\hline \multirow[t]{3}{*}{6} & \multirow[t]{3}{*}{ Logarithmic } & i) & $\frac{\mathrm{H}_{\mathrm{g}}}{\mathrm{H}_{0}}=0.34+0.40\left(\frac{n}{N}\right)+0.17 \log \left(\frac{n}{N}\right)$ & Newland (1988) \\
\hline & & ii) & $\begin{array}{c}\frac{\mathrm{H}_{\mathrm{g}}}{\mathrm{H}_{0}}=0.7517+0.371007\left(\frac{n}{N}\right)+0.000233\left(\frac{\theta_{\text {ave }}}{\theta_{\max }}\right) \\
-0.10309 \ln R H\end{array}$ & Argungu (2017) \\
\hline & & iii) & $\frac{\mathrm{H}_{\mathrm{g}}}{\mathrm{H}_{0}}=0.6433+0.576 \log \left(\frac{n}{N}\right)$ & Shahrukh 2019 \\
\hline \multirow[t]{2}{*}{7} & \multirow[t]{2}{*}{ Exponential } & ii) & $\frac{\mathrm{H}_{\mathrm{g}}}{\mathrm{H}_{0}}=-0.0271+0.3096 e^{\left(\frac{n}{N}\right)}$ & Almorox (2004) \\
\hline & & iii) & $\frac{\mathrm{H}_{\mathrm{g}}}{\mathrm{H}_{0}}=0.2776 e^{0.9324\left(\frac{n}{N}\right)}$ & Shahrukh (2019 \\
\hline \multirow[t]{2}{*}{8} & \multirow[t]{2}{*}{ Power } & i) & $\frac{\mathrm{H}_{\mathrm{g}}}{\mathrm{H}_{0}}=0.7316\left(\frac{n}{N}\right)^{0.4146}$ & Togrul (2002) \\
\hline & & ii) & $\frac{\mathrm{H}_{\mathrm{g}}}{\mathrm{H}_{0}}=0.6499\left(\frac{n}{N}\right)^{0.5013}$ & Shahrukh 2019 \\
\hline 9 & Reverse & & $\frac{\mathrm{H}_{\mathrm{g}}}{\mathrm{H}_{0}}=a_{o}+a_{1}\left(\frac{n}{N}\right)+a_{2} /\left(\frac{n}{N}\right)$ & Alhassan (2017) \\
\hline
\end{tabular}

\section{Estimation of regression coefficients}

In table 2 the typical equations to obtain the values of regression coefficients $\mathrm{a}$ and $\mathrm{b}$ adopted by various authors have been presented. Rietveld [33] used the ratio of sunshine hour in finding the value of $a$ and b. Gariepy [34] included ambient air temperature and amount of precipitation in determining the values of regression coefficients. Dogniaux [35] obtained the values of $a$ and $b$ as a function of latitude of the location. Kilic [36] determined the coefficients $\mathrm{a}$ and $\mathrm{b}$ as a function of the solar declination $(\delta)$ in addition to both $\varphi$ and $\mathrm{Z}$, where $\mathrm{Z}$ is altitude of the location. Zabara [37] proposed monthly a and $b$ values of the modified Angstrom model as a third order function of maximum possible sunshine duration (n) and day length (N). Gopinathan [38] has included latitude, altitude and sunshine ratio to determine a and b. Soler [39] in 1990 included first order ratio of sunshine hours for regression coefficient ' $a$ ' and $2^{\text {nd }}$ order ratio of sunshine hour for coefficient ' $b$ '.

Table 2. Typical values of regression coefficient $a$ and $b$ obtained by various authors

\begin{tabular}{|l|c|c|}
\hline Author & a & b \\
\hline Rietveld (1978) & $0.10+0.24\left(\frac{n}{N}\right)$ & $0.38+0.08\left(\frac{n}{N}\right)$ \\
\hline Gariepy (1980) & $0.3791-0.0041 T-0.0176 P$ & $0.4810-0.0043 T+0.0097 P$ \\
\hline $\begin{array}{l}\text { Dogniaux and } \\
\text { Lemoine (1983) }\end{array}$ & $0.37022-0.00313 \varphi$ & $0.32029-0.00506 \varphi$ \\
\hline $\begin{array}{l}\text { Kilic and Ozturk } \\
(1983)\end{array}$ & $0.103+0.000017 Z+0.0198 \operatorname{Cos}(\varphi-\delta)$ & $0.533-0.165 \operatorname{Cos}(\varphi-\delta)$ \\
\hline
\end{tabular}




\begin{tabular}{|l|c|c|}
\hline Zabara (1986) & $0.395+1.247\left(\frac{n}{N}\right)+2.860\left(\frac{n}{N}\right)^{2}$ & $0.395+1.384\left(\frac{n}{N}\right)-3.249\left(\frac{n}{N}\right)^{2}$ \\
\hline $\begin{array}{l}\text { Gopinathan } \\
\text { (1988) }\end{array}$ & $-0.309+0.539 \cos \varphi-0.0693 \mathrm{~h}+0.29\left(\frac{n}{N}\right)$ & $-0.309+0.539 \cos \varphi-0.0693 \mathrm{~h}+0.29\left(\frac{n}{N}\right)^{3}$ \\
\hline Soler (1990) & $0.179+0.099\left(\frac{n}{N}\right)$ & $0.1640+0.1786\left(\frac{n}{N}\right)-1.0935\left(\frac{n}{N}\right)^{2}$ \\
\hline
\end{tabular}

\section{Estimation of sun shine hour}

The number of empirical models to estimate GSR has been developed by various authors based on sunshine hours where sunshine hour data is recorded. In case sunshine recorder is not available then Umoh [40] proposed equations using four parameters, such as Relative Humidity (RH), Temperature (T), Rainfall (RF) and Wind speed (W) to estimate the possible sunshine hour. The correlation coefficient $\mathrm{R}$ and standard error of estimate $\sigma$ give the accuracy of the model. The models have been summarized in Table 3. The study found that the correlation at S. No. 4 found to be best fit for the location. However, the highest value of $\mathrm{R}$ has been obtained in model given as

$$
\mathrm{S}=-26.758+0.297 \mathrm{RH}+1.489 \mathrm{~T}-11.016 \mathrm{RF}
$$

Table 3. Models to estimate sunshine hour

\begin{tabular}{|c|c|c|c|c|}
\hline S. No. & Variable & Model & $\mathrm{R}$ & $\sigma$ \\
\hline \multirow[t]{2}{*}{1} & \multirow[t]{2}{*}{ One } & $-1.584+0.715 \mathrm{~T}$ & 0.851 & 0.64112 \\
\hline & & $13.548-2.984 \mathrm{~W}$ & 0.652 & 0.92702 \\
\hline \multirow[t]{2}{*}{2} & \multirow[t]{2}{*}{ Two } & $3.488+0.590 \mathrm{~T}-1.294 \mathrm{~W}$ & 0.885 & 0.60060 \\
\hline & & $7.417-0.031 \mathrm{RH}-4.243 \mathrm{RF}$ & 0.788 & 0.79360 \\
\hline \multirow[t]{2}{*}{3} & \multirow[t]{2}{*}{ Three } & $-26.758+0.297 \mathrm{RH}+1.489 \mathrm{~T}-11.016 \mathrm{RF}$ & 0.943 & 0.45280 \\
\hline & & $12.155-0.039 \mathrm{RH}-2.449 \mathrm{RF}-1.458 \mathrm{~W}$ & 0.831 & 0.76091 \\
\hline 4 & Four & $-22.424+0.272 \mathrm{RH}+1.388 \mathrm{~T}-9.791 \mathrm{RF}-0.623 \mathrm{~W}$ & 0.950 & 0.45812 \\
\hline
\end{tabular}

\section{Development of typical correlation to estimate GSR}

Several authors have observed that multiple parameters give best fit rather than one variable, such as, sunshine hour, cloud cover, temperature, relative humidity and precipitation. Some of the estimation models, which use the multiple meteorological parameters are presented and classified based on their input parameters. Some typical correlations for the estimation of GSR have also been included.

Awachie [41] correlated the maximum ambient temperature, $T_{m}$ with the global solar radiation for Nsukka as:

$$
H_{g}=-8.7+0.8 T m
$$

Just knowing the maximum temperature of the location, GSR can be estimated.
Okundamiya [42] estimated non-linear correlation as a function of measured sunshine hour for many locations in Nigeria as

$$
\frac{\mathrm{H}_{\mathrm{g}}}{\mathrm{H}_{0}}=0.7349\left(\frac{1}{n}\right)
$$

Gana and Akpootu[43] introduced a model in which clearness index is inversely proportional to sunshine ratio for Kebbi, Nigeria as

$$
\frac{\mathrm{H}_{\mathrm{g}}}{\mathrm{H}_{0}}=0.747\left(\frac{1}{n / N}\right)
$$

Okonkwo and Nwokoye[44] proposed $2^{\text {nd }}$ order correlation as a function of maximum temperature

$$
\frac{\mathrm{H}_{\mathrm{g}}}{\mathrm{H}_{0}}=-3.386+0.220\left(T_{\max }\right)-0.43\left(T_{\max }\right)^{2}
$$

Kolebaje et al. [45] reported the following model as a function of temperature ratio for Ikeja, Nigeria.

This article can be downloaded from here: $\underline{w w w . i j a e m s . c o m}$ 


$$
\frac{\mathrm{H}_{\mathrm{g}}}{\mathrm{H}_{0}}=2.024-2.136\left(T_{R}\right)
$$

Okonkwo and Nwokoye [44] reported the $2^{\text {nd }}$ order model as a function of temperature ratio for Minna, Nigeria as:

$$
\frac{\mathrm{H}_{\mathrm{g}}}{\mathrm{H}_{0}}=-0.987+5.526\left(T_{R}\right)-4.536\left(T_{R}\right)^{2}
$$

Kolebaje and Mustapha [45] estimated the GSR using models as a function of temperature difference for Port Harcourt located in Nigeria.

$$
\frac{\mathrm{H}_{\mathrm{g}}}{\mathrm{H}_{0}}=-0.141+0.210(\Delta T)^{0.5}
$$

Second order difference between maximum and minimum temperature employing Hargreaves and Samani type model in the form [45]:

$$
\frac{\mathrm{H}_{\mathrm{g}}}{\mathrm{H}_{0}}=-2.441+1.4341(\Delta T)^{0.5}-0.2094\left((\Delta T)^{0.5}\right)^{2}
$$

Boluwaji and Oyedum [46] calibrated the following models as a function of temperature difference and length of the day for different stations in Nigeria.

$$
\frac{\mathrm{H}_{\mathrm{g}}}{\mathrm{H}_{0}}=0.346+0.217\left(\frac{\Delta T}{N}\right)
$$

Ayodele and Ogunjuyigbe [47] developed exponential model as a function of temperature difference and length of the day for Ibadan, Nigeria

$$
\frac{\mathrm{H}_{\mathrm{g}}}{\mathrm{H}_{0}}=0.24+e^{0.064\left(\frac{\Delta T}{N}\right)}
$$

Ayodele and Ogunjuyigbe [47] developed the following logarithm model as a function of temperature difference and length of the day for Ibadan, Nigeria as:

$$
\frac{\mathrm{H}_{\mathrm{g}}}{\mathrm{H}_{0}}=0.45+0.39 \log \left(\frac{\Delta T}{N}\right)
$$

Okundamiya and Nzeako [42] reported the model as a function of maximum temperature and temperature ratio for Abuja in Nigeria as:

$$
\frac{\mathrm{H}_{\mathrm{g}}}{\mathrm{H}_{0}}=-1.2560+0.3815\left(T_{R}\right)-0.05440\left(T_{\text {Max }}\right)
$$

Quansah et al. [48] calibrated the logarithm model as a function of temperature difference for Kumasi, Ghana as:

$$
\frac{\mathrm{H}_{\mathrm{g}}}{\mathrm{H}_{0}}=-0.155+0.26 \log \Delta T
$$

Kolebaje et al. [45] reported the following model as a function of relative humidity for Ikeja located in Nigeria.

$$
\begin{gathered}
\frac{\mathrm{H}_{\mathrm{g}}}{\mathrm{H}_{0}}=2.024-0.019(R H) \\
\frac{\mathrm{H}_{\mathrm{g}}}{\mathrm{H}_{0}}=3.266-0.306(R H)^{2}
\end{gathered}
$$

The cloud cover impacts the quantity of global solar radiation reaching to particular location due to its scattered effects. The cloud cover is directly proportional the global solar radiation. Okundamiya [49] proposed the following model for Abuja in Nigerian.

$$
\frac{\mathrm{H}_{\mathrm{g}}}{\mathrm{H}_{0}}=0.7506-0.6455(C)
$$

Adaramla [50] correlated the clearness index with precipitation as

$$
\frac{\mathrm{H}_{\mathrm{g}}}{\mathrm{H}_{0}}=0.5904-0.0218(P)
$$

Kolebaje et al. [46] fitted the following model for Ikejaas a function of temperature difference, relative humidity, temperature ratio and the day number of year $\mathrm{Y}$ as

$$
\frac{\mathrm{H}_{\mathrm{g}}}{\mathrm{H}_{0}}=3.866-7.3102\left(\frac{\Delta T+R H}{Y}\right)^{0.5}+2.135\left(T_{R}\right)
$$

The sunshine duration, temperature, relative humidity, latitude and day number in the year (Y) were incorporated as [51]

$$
\begin{aligned}
\mathrm{H}_{\mathrm{g}}=-3.6889 \operatorname{Cos} \varphi+29.309 \operatorname{Cos} Y+7652\left(T_{\text {Max }}\right) \\
+57.524\left(\frac{n}{N}\right)+7.9618\left(\frac{T_{\text {Max }}}{R H}\right) \\
+0.6421(R H)-3.6827(\operatorname{Cos} \varphi \operatorname{Cos} Y) \\
\\
-8.855\left(\frac{T_{\text {Max }}}{R H}\right)+0.499\left(\frac{T_{\text {Max }}}{R H}\right)^{2} \\
+91.308\left(\frac{n}{N}\right)-2.9855 \operatorname{Cos}^{2} Y-61.20
\end{aligned}
$$

Coulibaly and Ouedoraogo [52] developed a model to estimate GSR as a function of extra-terrestrial solar radiation $\left(\mathrm{H}_{\mathrm{O}}\right)$, sunshine duration, maximum temperature, clearness index and solar declination angle were incorporated with global solar radiation $\left(\mathrm{H}_{\mathrm{g}}\right)$ in the form.

$$
\begin{aligned}
\mathrm{H}_{\mathrm{g}}=-58791.68 & +1.76 \mathrm{H}_{0}+36191.21\left(\frac{n}{N}\right) \\
& -13.37\left(\frac{\mathrm{H}_{\mathrm{g}}}{\mathrm{H}_{0}}\right)-298.69\left(T_{\text {Max }}\right) \\
& -9805.01 f(\operatorname{Sin} \delta)
\end{aligned}
$$

Tikyaa [53] developed 15 models for Katsina to estimate GSR. The proposed model was found to be best with $\mathrm{R}^{2}=$ 0.941 and small value of RMSE (0.02531)

$$
\frac{\mathrm{H}_{\mathrm{g}}}{\mathrm{H}_{0}}=-0.2144(\Delta T)^{0.02062}
$$

\section{Intelligent techniques to develop models}

The techniques to solve the problem of proposed models since they are non-linear and complex in nature, have classified in two general categories: Statistical Regression Techniques (SRTs) and intelligent methods Bagheri [54]. In the intelligent category, Mellit et al. [55] offered an artificial neural network model for prediction solar

This article can be downloaded from here: www.ijaems.com 
radiation data. A fuzzy model for the prediction of solar radiation has been proposed [56], genetic algorithm optimization of wavelet neural network for estimating solar radiation [57] and a new model for predicting GSR using Particle Swarm Optimization (PSO) technique [58]. Despotovic [59] has proposed Global Performance Indicator to determine the best fit of predicted GSR for any location globally. Soft computing models which can accept many input variables are found to estimate global solar radiation accurately and reliable in different climate conditions across the globe [7]. Kumar et al [60] have compared regression technique and ANN to estimate GSR and found that the ANN produced more accurate results.

\section{CONCLUSIONS}

The number of models and techniques to estimate GSR has been presented. All the models found to be best fit for their locations. During last 10 years as the emissions of GHGs have increased drastically, it is hard to see blue sky in many cities across the globe. Suthar [32] has realized this aspect and included the air pollution index in their study to estimate GSR. The environmental parameters need to be included while estimating global solar radiation.

\section{ACKNOWLEDGEMENT}

The facilities provided by the department of environmental Science, Dr YSP University of Horticulture \& Forestry, Nauni (Solan) HP, India.

\section{REFERENCES}

[1] Intergovernmental Panel on Climate Change. Summary for Policymakers. 2018

[2] J.L. Souza, G.B. Lyra, C.M.D. Sanobs, R.A. Feneiru Junior, C. Tibu, G.B.Lyra, M.A. M. Lemes. Empirical models of daily and monthly global solar irradiation using sunshine duration for Alagoas State, Northeastern Brazil, Sustainable Energy Technol. Assess., 2016; 14: 35-45.

[3] Besharat, F., Dehghan, A., Faghih, A.R. Empirical models for estimating global solar radiation: a review and case study. Renewable Sustainable Energy Rev. 2013;21: 798821.

[4] Ertekin, C., Yaldiz, O. Estimating of monthly average daily global radiation on horizontal surface for Antalya, Turkey. Renewable Energy. 1999;17: 95-102.

[5] Angstrom A. Solar and terrestrial radiation. Quarterly Journal of Royal Meteorological Society.1924; 50: 121 125.

[6] Prescott, J. Evaporation from a Water Surface in Relation to Solar Radiation. Transactions of the Royal Society of South Australia.1940; 64: 114-118.

[7] Samuel Chukwujindu Nwokolo, Julie C. Ogbulezie. A quantitative review and classification of empirical models for predicting global solar radiation in West Africa. BeniSuef University Journal of Basic and Applied Sciences.2018; 7: 367-396.

[8] Page J.K. The estimation of monthly mean values of daily total short wave radiation on vertical and inclined surface from sunshine records for latitudes $40 \mathrm{~N}-40 \mathrm{~S}$. Proceedings of UN Conference on New Sources of Energy 1961; 4(598): 378-390.

[9] Glover J., McGulloch J.D.G. The empirical relation between solar radiation and hours of sunshine. Quarterly Journal of the Royal Meterological Society. 1958; 84: 172175.

[10] Togrul I.T., Onat E. A study for estimating solar radiation in Elazig using geographical and meteorological data. Energy Conversion and Management. 1999; 40: 15771584.

[11] Hay J.E. Calculation of monthly mean solar radiation for horizontal and inclined surfaces. Solar Energy. 1979; 23(4): 301-307.

[12] Rensheng C., Ersi K., Jianping Y., Shihua L., Wenzhi Z. Validation of five global radiation models with measured daily tada in China. Energy Conversion and Management. 2004; 45:1759-1769.

[13] Ogelman, H., Ecevit, A., and Tasdemiroglu, E. A new method for estimating solar radiation from bright sunshine data. Solar Energy. 1985; 33: 619-625

[14] Bahel V., Srinivasan R., Bakhsh H. Solar radiation for Dhahran, Saudi Arabia. Energy 1986; 11: 985-989.

[15] Md. Shahrukh Anis, Basharat Jamil, Md. Azeem Ansar, Evangelos Bellos. Generalized Models for Estimation of Global Solar Radiation based on Sunshine ispepiration and Detailed Comparison with the Existing: A Case Study for India. Sustainable Energy Technologies and Assessments. 2019; 31:179-198.

[16] Bakirci K. Correlations for estimation of solar radiation on horizontal surface. Journal of Energy Engineering 2008; 134(4): 130-134.

[17] G. M. Argungu and K. A. Dabai. Application of Linear Models for Estimation of Global Solar Radiation using Available Meteorological Parameters for Sokoto, Nigeria. IJASRE. 2017;3(11):76-83

[18] Almorox J., Hontoria C. Global solar radiation estimation using sunshine duration in Spain. Energy Conversion and Management. 2004;45:1529-1535.

[19] Togrul, İ. T. and Togrul, H. Global solar radiation over Turkey: Comparison of predicted and measured data, Renewable Energy. 2002

[20] Alhassan Ali Teyabeen and Ali Elseddig Jwaid (2017). Sunshine Duration-Based Models for Predicting Global Solar Radiation, UKSim-AMSS 19th International Conference on Modeling \& Simulation. 2017. 168-172.

[21] Newland F.J. A study of solar radiation models for the coastal region of South China. Solar Energy. 1988; 31: 227-235.

[22] Gadiwala, M. S., Usman, A., Akhtar, M., and Jamil, K., "Empirical models for the estimation of global solar radiation with sunshine hours on horizontal surface in

This article can be downloaded from here: www.ijaems.com 
various cities of Pakistan,” Pakistan J. Meteorol. 2013; 9(18): 43-49.

[23] Ninomiya, H., "Study on application of a medas meteorological data to the simulation of building heat environment", University of Tokyo. (1994)

[24] Chandel SS, Aggarwal RK and Pandey AN (2005). New Correlation to Estimate Global Solar Radiation on Horizontal Surfaces Using Sunshine Hour and Temperature Data for Indian Sites. Solar Energy Engineering Journal, 127(3): 417-420.

[25] V.K. Marwal, R.C. Punia, N. Sengar, S. Mahawar and P. Dashora. A comparative study of correlation functions for estimation of monthly mean daily global solar radiation for Jaipur, Rajasthan (India), Indian Journal of Science and Technology. 2012; 5(5):2729-2732.

[26] KadirBakirci. Models for Determination of Solar Energy Potential. ENERGY EXPLORATION \& EXPLOITATION. 2008; 26(5): 281-292.

[27] R. Meenal ; A. Immanuel Selvakumar. Estimation of global solar radiation using sunshine duration and temperature in Chennai International Conference on Emerging Trends in Engineering, Technology and Science (ICETETS). 2016.

[28] Aicha Soufi, Ali Chermitti, Bouzaki Mohamed Mostafa and Allam Zehor. Investigating the Performance of Chosen Models for the Estimation of Global Solar Radiation on Horizontal Surface - A Case Study in TernyHdiel, Tlemcen of Algeria, Journal of Engineering Science and Technology Review. 2014; 7(3):45-49

[29] Muhammad Jamilu Ya'u, Muhammad Abdullahi Gele, Yerima Yusif Ali, Abdulkarim Mika'ilAlhaji. Global Solar Radiation Models: A Review, Journal of Photonic Materials and Technology. 2018; 4(1): 26-32.

[30] Aggarwal R K (2009). New correction factor for the estimation of solar radiation, J. of Renewable and Sustainable Energy, 1(1): 9-14.

[31] Rajesh Kumar, Ritesh Verma and R K Aggarwal (2018). Empirical model for the estimation of global solar radiation for Indian locations. International Journal of Ambient Energy, 10.1080/01430750.2018.1525588

[32] Mamta Suthar, G K Singh and R P Saini. Effects of air pollution for estimating global solar radiation in India. International Journal of Sustainable Energy.2014: 20-27.

[33] Rietveld M.R. A new method for estimating the regression coefficients in the formula relating solar radiation to sunshine. Agricultural Meteorology. 1978; 19: 243-252.

[34] Gariepy J. Estimation of global solar radiation. International Report, Service of Meteorology, Government of Quebec, Canada, 1980.

[35] Dogniaux R., Lemoine M. Classification of radiation sites in terms of different indices of atmospheric transparency. Solar energy research and development in the European Community, Series F, vol. 2. Dordrecht, Holland, Reidel, 1983

[36] Kilıc A., Ozturk A. Solar energy, Kipas, Distribution, Istanbul, 1983.

[37] Zabara K. Estimation of the global solar radiation in Greece. Solar and Wind Technology. 1986; 3(4): 267-272.
[38] Gopinathan K.K. A general formula for computing the coefficients of the correlations connecting global solar radiation to sunshine duration. Solar Energy. 1988; 41:499502

[39] Soler A. Monthly specific Rietveld's correlations. Solar and Wind Technology. 1990; 7: 305-308.

[40] Umoh, M. D., Udo S. O and Udoakah, Y. N. Global solar radiation studies due to sunshine hours and other meteorological parameters. American Journal of Engineering and Applied Sciences. 2013; 6 (3): 320-326.

[41] Awachie, I.R.N and Okeke, C.E.New empirical solar model and its use in predicting global solar irradiation. Nigerian J. Solar Energ. 1990; 9: 143-156.

[42] Okundamiya, M.S., Nzeako, A.N., 2011. Empirical model for estimating global solar radiation on horizontal surfaces for selected Cities in the six Geopolitical zones in Nigeria. J. Control Sci. Eng. http://dx.doi.org/10.1155/2011/356405.

[43] Gana, N.N., Akpootu, D.O., 2013. Angstrom type empirical correlation for estimating global solar radiation in NorthEastern Nigeria. Int. J. Eng. Sci. 2, 58-78.

[44] Okonkwo, G.N., Nwokoye, A.O.C., 2014. Estimating global solar radiation from temperature data in Minna location. Eur. Sci. J. 10, 1857-7431.

[45] Kolebaje, O.T., Sika, A.I., Akinyemi, P., 2016. Estimating solar radiation in Ikeja and Port Harcourt via correlation with relative humidity and temperature. Int. J. Energy Prod. Manage. 1 (3), 253-262.

[46] Boluwaji, M.O., Onyedi, D.O., 2016. Comparative study of ground measured, satellite-derived, and estimated global solar radiation data in Nigeria. J. Sol. Energy 10, 1-7.

[47] Ayodele, T.R., Ogunjuyigbe, 2016. Performance assessment of empirical models for prediction of daily and monthly average global solar radiation: the case study of Ibadan, Nigeria. Int. J. Ambient Energy. http://dx.doi.org/10.1080/ 01430750.2016.

[48] Quansah, E., Amekudzi, L.K., Preko, K., Aryee, J., Boakye, O.R., Boli, D., Salifu, M.R., 2014. Empirical models for estimating global solar radiation over the Ashanti Region of Ghana. J. Sol. Energy, 1-7.

[49] Okundamiya, M.S., Emagbethre, J.O., Ogujor, E.A., 2016. Evaluation of various global solar radiation models for Nigeria. Int. J. Green Energy 13, 505-512.

[50] Adaramola, M.S., 2012. Estimating global solar radiation using common meteorological data in Akura, Nigeria. Renewable Energy 47, 38-44.

[51] Ajayi, O.O., Ohijeagbon, O.D., Nwadialo, C.E., Olasope, O., 2014. New model to estimate daily global solar radiation over Nigeria. Sustainable Energy Technol. Assess. 5, 28-36.

[52] Coulibaly, O., Ouedoraogo, A., 2016. Correlation of global solar radiation of eight synoptic stations in Burkina Faso based on linear and multiple linear regression methods. J. Sol. Energy, 1-12.

[53] Tikyaa, E.V., Akinbolati, A. and Shehu, M. Assessment of empirical models for estimating mean monthly global solar radiation in Katsina. FUDMA Journal of Sciences (FJS).2019; 3(1): $333-344$ 
[54] H.Bagheri Tolabi, M. H. Moradi, F. Bagheri Tolabi. New Technique for Global Solar Radiation Forecast using Bees Algorithm, IJE TRANSACTIONS B: Applications. 2013; 26(11):1385-1392.

[55] Mellit, A., Menghanem, M. and Bendekhis, M., "Artificial neural network model for prediction solar radiation data: Application for sizing stand-alone photovoltaic power system", in Power Engineering Society General Meeting, IEEE. 2005: 40-44.

[56] Iqdour, R. and Zeroual, A., "A rule based fuzzy model for the prediction of solar radiation", Revue Des Energies Renouvelables. 2006; 9(2): 113-120.

[57] Wang, J., Xie, Y., Zhu, C. and Xu, X., "Daily solar radiation prediction based on genetic algorithm optimization of wavelet neural network", in Electrical and Control Engineering (ICECE), International Conference on, IEEE. 2011: 602-605.

[58] Behrang, M., Assareh, E., Noghrehabadi, A. and Ghanbarzadeh, A., "New sunshine-based models for predicting global solar radiation using pso (particle swarm optimization) technique", Energy. 2011; 36(5): 3036-3049.

[59] Despotovic M, Nedic V, Despotovic D, Cvetanovic S. Review and statistical analysis of different global solar radiation sunshine models. Renew Sustain Energy Rev 2015;52:1869-80.

[60] Rajesh Kumar, R.K. Aggarwal, J.D. Sharma (2015). Comparison of regression and artificial neural network models for estimation of global solar radiations. Renewable and Sustainable Energy Reviews, 52: 1294-1299. 